\title{
PROSTHODONTIC REHABILITATION OF PATIENTS WITH DOUBLE CROWN AND LOCATOR ATTACHMENT - RETAINED OVERDENTURES SUPPORTED BY A COMBINATION OF NATURAL TOOTH AND STRATEGIC IMPLANTS: CASE SERIES
}

Marko Milosavljevic ${ }^{1}$, Milica Jovanovic ${ }^{1}$, Dejan Zdravković ${ }^{1}$, Jelena Todic ${ }^{2}$, Jelena Eric ${ }^{3}$ ${ }^{1}$ Department of Dentistry, Faculty of Medical Sciences, University of Kragujevac, Kragujevac, Serbia ${ }^{2}$ Department of Dentistry, Faculty of Medicine, University of Priština/Kosovska Mitrovica, Kosovska Mitrovica, Serbia ${ }^{3}$ Department of Prosthodontics, Faculty of Medicine, University of East Sarajevo, Foca, Bosnia and Herzegovina

\section{PROTETSKA REHABILITACIJA PACIJENATA SUPRADENTALNIM PROTEZAMA PODUPRTIH KOMBINACIJOM PRIRODNIH ZUBA I DENTALNIH IMPLANATA, SA DVOSTRUKIM KRUNAMA I ATEČMENIMA TIPA LOKATORA: SERIJA SLUČAJEVA}

\author{
Marko Milosavljević ${ }^{1}$, Milica Jovanovići ${ }^{1}$, Dejan Zdravkovići ${ }^{1}$ Jelena Todić ${ }^{2}$, Jelena Erić ${ }^{3}$ \\ ${ }^{1}$ Katedra za Stomatologiju, Fakultet Medicinskih Nauka, Univerzitet u Kragujevcu, Kragujevac, Srbija \\ ${ }^{2}$ Katedra za Stomatologiju, Medicinski fakultet, Univerzitet u Prištini/Kosovska Mitrovica, Kosovska Mitrovica, Srbija \\ ${ }^{3}$ Katedra za Protetiku, Medicinski fakultet, Univerzitet u Istočnom Sarajevu, Foča, Bosna i Hercegovina
}

\begin{abstract}
Prosthetic rehabilitation of edentulous patients and patients with one or two own teeth can be established by different treatment modalities. The most commonly used in the treatment of these patients is conventional complete denture or removable partial denture. However, due to increasing problems with this type of therapy, such as insufficient retention, stability, comfort and pain during mastication, it is suggested an overdenture supported by two natural teeth or implants. We will present series of clinical reports. In two clinical cases patients came to the dental office because of the impossibility of wearing lower partial denture, and in one case patient had problems with the upper partial denture. After clinical examination and radigraphic analysis, in all patients, dental implants were implanted. In first case there were implanted two dental implants in the region 41 and 43, in second case it was region 33, and in third case implanatiton is performed in the region of 14, 11, 21. Prosthetic rehabilitation was done after 3-months bone oseointegration period. The treatment consisted in the production of double crowns and overdentures that are retained with locator attachment. This design of the denture significantly improves the quality of patient's life (the dentures are stable, chewing is improved, the feeling of thermal sensations of food and drink is present, the feeling of taste is complete, and the psychological patient becomes safer).
\end{abstract}

Keywords: overdenture, double crown, locator, dental implant.

\section{SAŽETAK}

Protetska rehabilitacija bezubih pacijenata i pacijenata sa jednim ili dva svoja zuba može se izvršiti različitim tarpijskim modalitetima. U terapiji ovih pacijenata najčešće se koristi konvencionalna totalna proteza ili parcijalna proteza. Međutim, zbog sve većih problema sa ovom vrstom terapije, kao što su nedovoljna retencija, stabilnost, udobnost i bol tokom žvakanja, predlaže se izrada supradentalne proteze koja je poduprta sa dva prirodna zuba ili implantata. Ovde je prikazana serija kliničkih slučajeva, u dva klinička slučaja pacijenti su došli u stomatološku ordinaciju zbog nemogućnosti nošenja donje parcijalne proteze, dokje u jednom slučaju pacijent imao problema sa gornjom parcijalnom protezom. Nakon kliničkog pregleda i radiografske analize, kod svih pacijenata ugrađeni su dentalni implantati. U prvom slučaju ugrađena su dva implantata u području 41 i 43, u drugom slučaju u području 33, a u trećem su ugrađeni u regionu 14, 11, 21. U svim slučajevima nakon perioda oseointegracije od 3 meseca izvršena je protetska sanacija. Tretman se sastojao od izrade dvostrukih krunica i supradentalnih proteza koje su retinirane lokator atečmenima. Ovaj dizajn proteze značajno poboljšava kvalitet života pacijenta (proteze su stabilne, žvakanje je poboljšano, osećaj termičkih senzacija hrane i pića je prisutan, osećaj ukusa je potpun, a psihološki pacijent postaje sigurniji).

Ključne reči: supradentalna proteza, dvostruka kruna, lokator, implantat.

\section{ABBREVIATIONS}

CBCT - Cone beam computed tomography

RPD - Removable partial denture

\section{sciendo}

UDK: $616.314-77$

616.314-089.28

Ser J Exp Clin Res 2021; 22 (4): 363-370

DOI: $10.2478 /$ sjecr-2019-0038
Corresponding author: Marko Milosavljević, DDS, PhD, Research assistent Address: Zmaj Jovina 32, 34000 Kragujevac, Serbia Tel: +381 34355 840; Mob: 0637725138
E-mail: drm.milosavljevic@yahoo.com 


\section{INTRODUCTION}

Prosthetic rehabilitation of an edentulous mandible can be established by using different treatment modalities. Conventional complete dentures are a common prosthodontic treatment used for the replacement of all missing teeth. However, patients wearing complete denture often suffer from a variety of problems with their dentures, especially in the lower jaw, such as insufficient retention, stability, comfort and pain during mastication. With time, the resulting difficulties can compromise patient's oral functions (choice and enjoyment of food, chewing efficancy and nutritional intake), esthetics and may result in a range of emotional reactions in edentulous people $(1,2)$. Also, complete denture does not stimulate alveolar bone adequately as natural teeth does. The lack of periodontal mechanoreceptors can lead to overloading of denture bearing areas during masticatory function resulting in higher resorption rate $(3,4)$. For these reasons, conventional complete denture have been modified to gain additional support and stability from a few retained natural teeth or implants. The use of an overdenture supported by two natural teeth or implants shows some advantages over the complete denture treatment such as decreased resorption of the alveolar ridge $(5,6)$, improved retention and stability of the dentures, grater satisfaction and improved patients' quality of life (7). Such caracteristics associated with the high success rate in implant treatment $(8,9)$, make the overdenture retained by two implants the standard treatment for the edentulous mandible.

Many types of attachments can be used for connecting overdenture to natural teeth and implants $(10,11)$ and their correct selection is very important for successfull prosthetic treatment. Telescopic crowns as retainers between natural teeth and overdentures have been used successfully in clinical practice (10). This type of retainer provides good retention and stability of overdenture, the transmission of masticatory load along the long axis of the abutment teeth, maintainance sensory feedback and protection from dislodging movement. Apart from being used as retainers for connecting natural teeth and overdenture, telescopic crowns have been used to retain implant-supported overdentures with long-term denture and implants survival rates $(11,12,13)$. Also, mandibular implant-supported overdentures may be successifully retained with ball, bar, locator and magnetic attachments (14).

In unfavorable prosthetic baseline situations with reduced number of abutment teeth, the use of implants in strategic positions on the opposite side of the dental arch is nedeed to equalize the balance and create suitable support and retention. The combined use of implant and natural teeth to support an overdenture presents a certain biomechanical challenge due to the dissimilar mobility between the abutments and different mechanism of absorption and dissipation of forces on supporting tissues. This treatment option has been disputed in dental literature $(15,16)$, but it offers an extensive and almost unlimited spectrum of new treatment possibilities $(17,18)$. Therefore, this clinical report describes the prosthetic rehabilitation of patients with double crown and locator attachments-retained overdentures supported by a combination of natural tooth and strategic implants.

\section{CASE REPORT 1}

The 67-year-old patient came to the dental office for impossibility of wearing the lower removable partial denture (RPD). Based on patient`s history and clinical examination, inadequate stabilization and retention of lower RPD was revealed. The analysis of the anamnestic questionnaire found that the patient does not have general chronic diseases and does not use any type of therapy. Implant planning and implantation of dental implant was performed on the basis of Cone beam computed tomography (CBCT) analysis and evaluation. In the dental status in the lower jaw on the left side there was an endodontically treated caninus, whose periodontal status was good. In the upper jaw there was combined prosthetic restoration with attechments. After implantation of dental implant in the region 41 and 43 (Implant direct legacy 3, USA), and the 3-month bone oseointegration period, the prosthetic rehabilitation of the patient was done. The tooth is reinforced with Fiber-reinforced composite posts (FRC Postec Plus, size 1, Ivoclar, Vivadent, Liechtenstein) and cemented with composite cement (Multilink Automix, Ivoclar, Vivadent, Liechtenstein).

Before the start of prosthetic rehabilitation, both implants were opened and gingival binders were implanted. In the first phase of prosthetic rehabilitation, preparation of the tooth 33 was done, and the impression was taken by double method using addition elastomeric material (Elite P \& P Putty Soft, Elite HD + Regular Body Normal Set, Zhermack, Italy) with the previous application of retraction thread (Ultrapak No 0, Ultradent, USA). In the same visit, the depth of the sulcus for future locators was measured (the implant platform for the locator was $3.5 \mathrm{~mm}$ and the height of both locators was 2 $\mathrm{mm})$. After the telescope double crown system was completed (milling of the inner telescope was $6^{\circ}$ ), an inner telescope crown was examined and its attachment to the prepared tooth was checked, after which an outer telescope crown was made. Then the relation of the outer and inner telescopes to the prepared tooth was checked. Prior to taking a functional impression, locators implant attachment of mentioned dimensions (Zest Dental Solutions, USA), which are tightened on the $30 \mathrm{Ncm}$ with torque wrench, were set up using the locator square driver $15 \mathrm{~mm}$ wrench. Also, female parts of the locator with working tires (black color) were set up, after which the anatomical impression was taken. On an anatomical model, an individual tray with interspace was made, according to all principles of extension as for full denture. After the verification of the telescope, a functional impression of lower jaw was taken using elastomeric impression material (the functional impression was taken by all principles as for full denture), thermoplastic mass (Impression Compound, Harvard, Germany) was used for shaping the edges of the individual tray and the elastomeric impression material in the individual tray (Xantopren M mucosa, Heraeus Kulzer 
GmbH, Germany), using an adhesive for individual tray (Universal Adhesive, Heraeus, Germany). The reason for taking definitive impression over the female parts of the locator is that the technician makes perforations in the framework and later the interspace for cold-polymerizing acrylate for the direct attachment of the denture to the female part of the locator.

Outpouring a functional impression it was obtained a working model for making of a RPD framework, and later a model for completing this prosthetic restoration. After RPD framework was completed, in dental office cheking of framework, determination of jaw relationship and the colour of the teeth was done. In next phase cheking of teeth setting, verification of jaw relationship, as well as shape and position of the teeth was done, after which restoration was sent to the laboratory for the definitive ending.

The specificity of the ending of restoration in clinical work is that the female part of the locator is first connected with a cold-polymerizing acrylate for denture (prior it is necessary to prepare the locator system, a white ring is placed on it, that prevents onflow of liquid acrylate along the abutment of locator, and female part of the locator is placed over that). On the lingual side of the denture, in the area for the female part of the locator, perforations were made in order to extract the surplus of the acrylate, so as not to remain trapped gingival. After bonding the acrylate, on the female part of the locator there are working rubbers (black). After removal of the denture from the oral cavity, the working rubber was removed by LOCATOR ${ }^{\circledR}$ Core Tool key and a $0-10^{\circ}$ rubber was set, i.e. $10-20^{\circ}$ depending on the need to correct the disparity. In this patient, rubbers that tolerate diparality up to 10 degrees (retention forces of $3.0 \mathrm{lbs}$ ) were placed (Figure 1).

Figure 1. Gingival display of the denture with 10 degree rubbers, retention forces $3.0 \mathrm{lbs}$

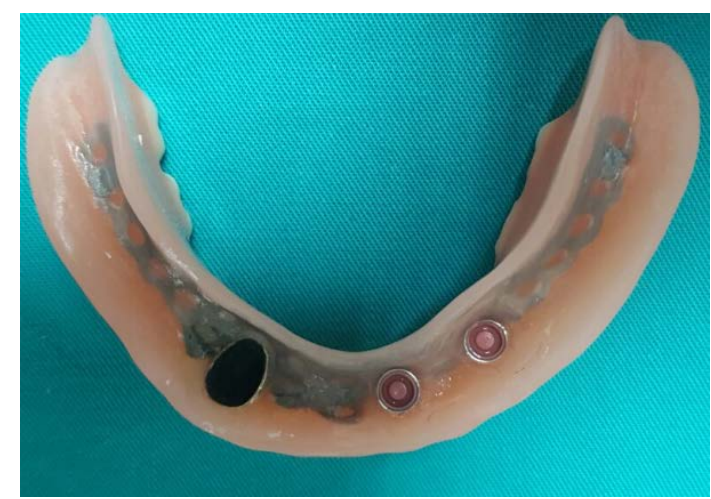

After that, the cementing of the telescope to the tooth 33 was done with all the preparations that require the cementing of the telescope system (vaseline isolation of the inner surface of the outer telescope crown and the outer surface of the inner telescope crown) (Figure 2).
Figure 2. Isolation with vaseline of the outer surface of the inner crown

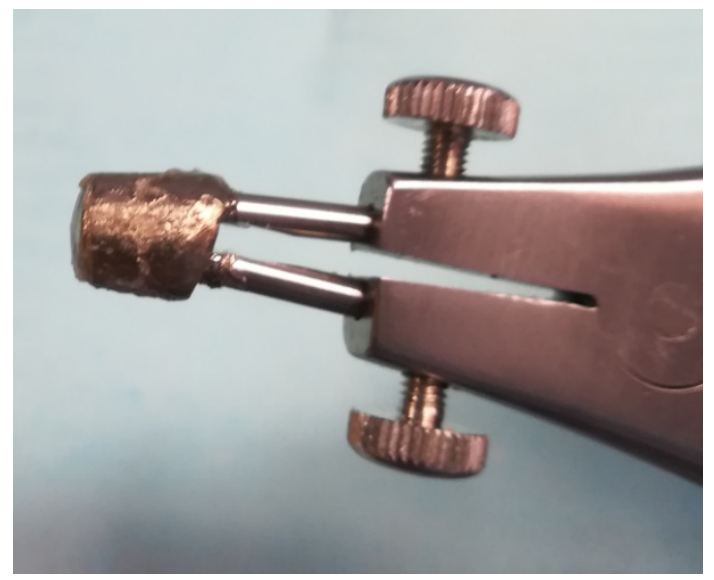

Zinc phosphate cement (Harvard, Germany) was used for the cementing of the inner telescope crown. After cementing the telescope system, the surplus of zinc phosphate cement was removed, which was visible to the naked eye. A possible correction of the occlusion with articulation paper of $80 \mu$ (Coltene / Whaledent) was made. On the control examination after 24 hours, the denture was removed (Figure 3, Figure 4, Figure 5). Instruction of the patient for removal and putting the denture was performed, instructions for maintenance of oral hygiene and denture were given to the patient. Also, during the examination, the reocclusion with articulation paper of $80 \mu \mathrm{m}$ was done. At the controls of every 3 months, the presence of periimplantitis or bone resorption around the implant, as well as bone resorption around the teeth carrying the telescope crown, was not clinically and radiographically established.

Figure 3. Review of male parts of locator and inner conus telescop system

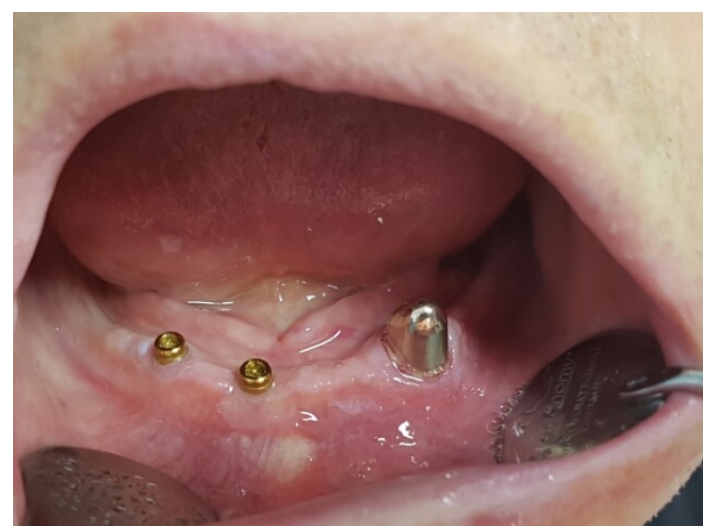


Figure 4. Definitive prosthetic restoration

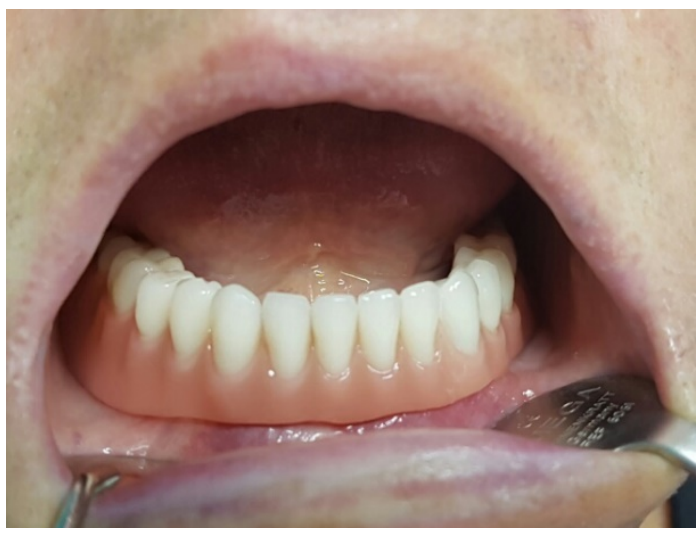

Figure 5. Definitive prosthetic restoration lingual aspect

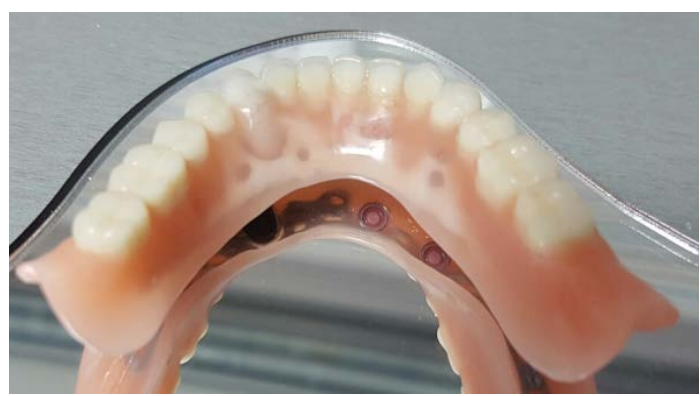

\section{CASE REPORT 2 - THE SPECIFICITY OF THE CASE}

A 55-year-old patient came to dental office for inadequate stabilization and poor retention of the lower RPD. The analysis of the anamnestic questionnaire found that the patient does not have general chronic diseases and does not use any type of therapy. Implant planning and implantation of dental implant was performed on the basis of CBCT analysis and evaluation. In the dental status in the lower jaw on the left side there was an intact first premolar. In the upper jaw there was a complete denture. After implantation of dental implant in region 33 (Implant direct legacy 3, USA), and 3-month bone oseointegration period, a prosthetic rehabilitation of the patient was done. All clinical and laboratory phases are exactly the same as in the previous case. The difference is that the disparity between the axis of the implant and the axis of the tooth is greater than 10 degrees, so the rubbers that correct the disparity of 10-20 degrees were placed. At the controls of every 3 months, the presence of periimplantitis or bone resorption around the implant, as well as bone resorption around the teeth carrying the telescope crown, was not clinically and radiographically established. Review of clinical phases (Figure 6 - 10).
Figure 6. Intraoral review after impression

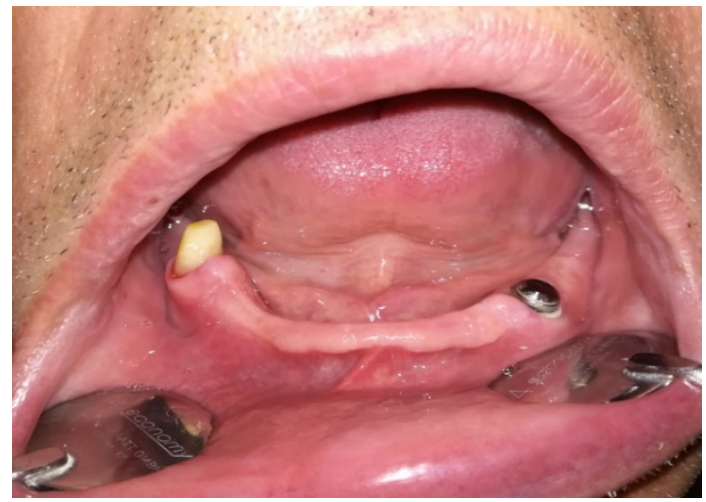

Figure 7. Functional impression of lower jaw with elastomeric impression material

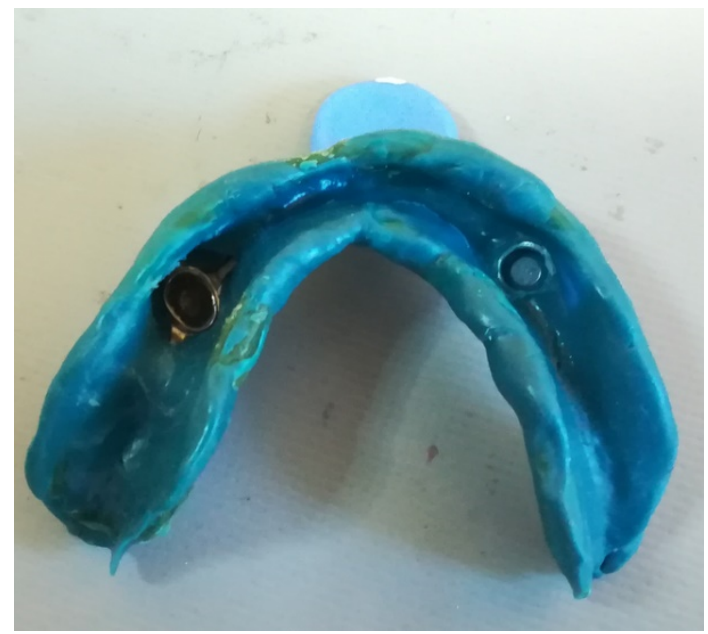

Figure 8. Gingival aspect of denture with working rubber (black)

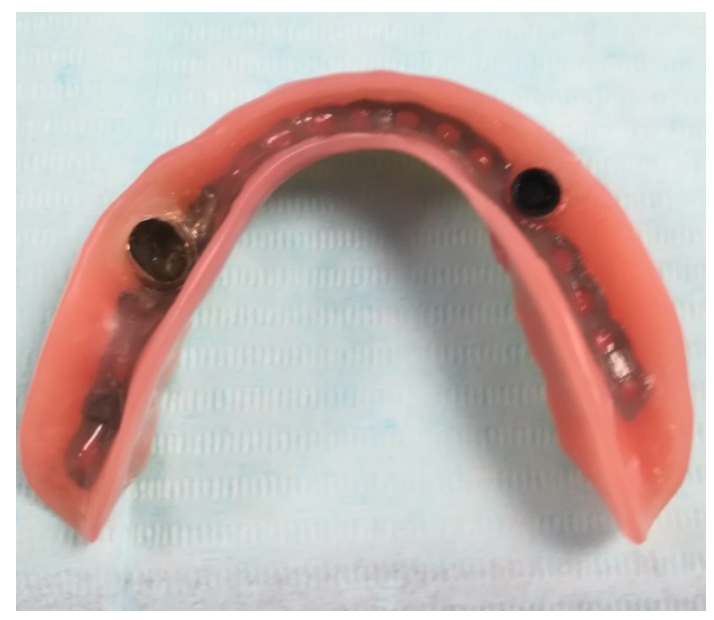


Figure 9. Gingival aspect of denture with rubber that correct disparity till 20 degrees, retention forces 2,0 lbs

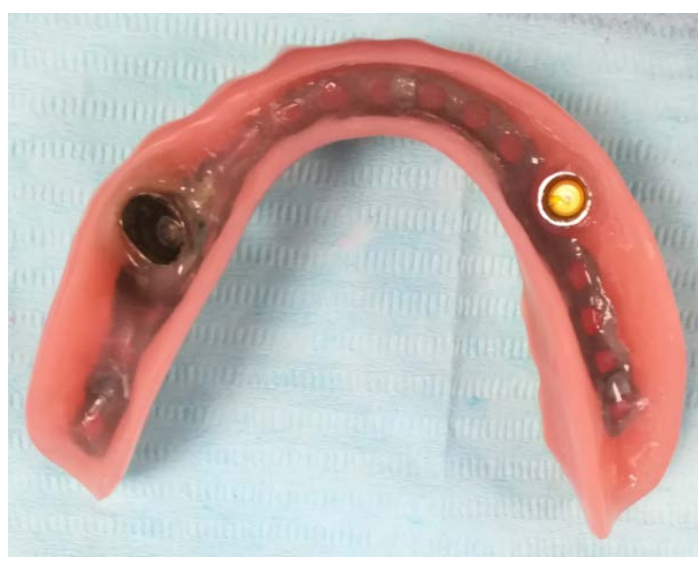

Figure 10. Lingual aspect of definitive prosthetic restoration

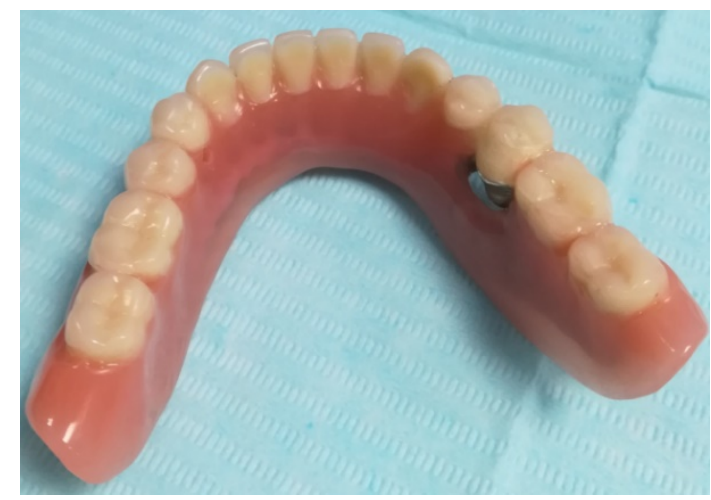

\section{CASE REPORT 3 - THE SPECIFICITY OF THE CASE}

A 67-year-old patient came for inadequate stabilization and poor retention of the upper RPD. The analysis of the anamnestic questionnaire found that the patient does not have general chronic diseases and does not use any type of therapy. During intraoral clinical examination, in the upper jaw the presence of RPD with poor retention and stabilization and abraded teeth was detected, while in the lower jaw there was a complete denture on one telescope system. After talking with the patient, prosthetic treatment with implantation of dental implant at strategically important positions and making of combined supported overdenture was proposed.

Dental implants were implanted in the region of 14, 11, 21 (Straumann bone level implant, Basel, Switzerland) and 3-month bone oseointegration period, prosthetic rehabilitation of the patient was done. In the dental status in the upper jaw on the right side there is an intact second molar. All clinical stages are exactly the same as in the previous case. The difference is in the technical phase in which the female parts of the locator in the intercanine segment were coated with an opaque because the implants were embedded in the alveolus of the extracted teeth, and after the period of the oseointegration due to vestibular resorption of the bone, implants were too vestibulary (Figure 11). Also, the difference is that the rubbers on the locators in region 11, 21 were of 10-20 degrees. At the controls of every 3 months, the presence of periimplantitis or bone resorption around the implant, as well as bone resorption around the teeth carrying the telescope crown, was not clinically and radiographically established. Review of clinical phases (Figure 11-14).

Figure11. Intraoral finding with female parts of locator system

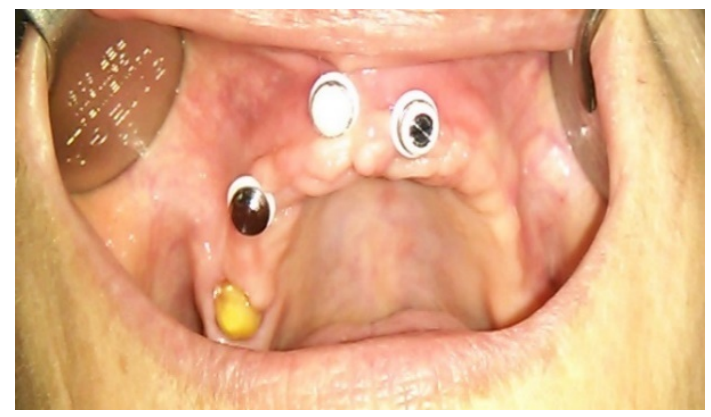

Figure 12. Intraoral finding after cementing of telescop system

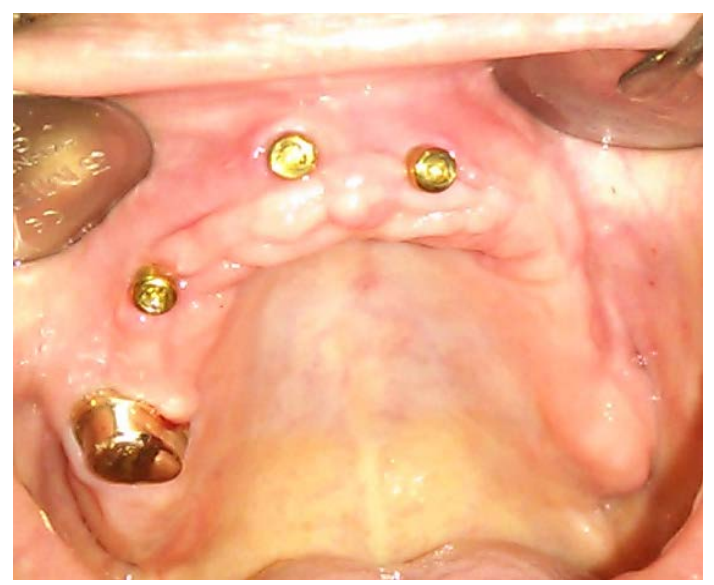

Figure 13. Occlusal aspect of prosthetic restoration

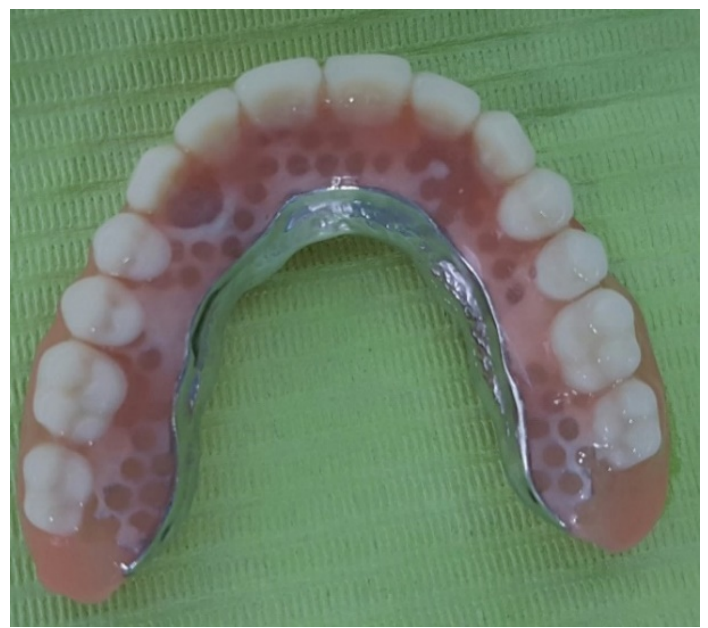


Figure 14. Definitive prosthetic restoration

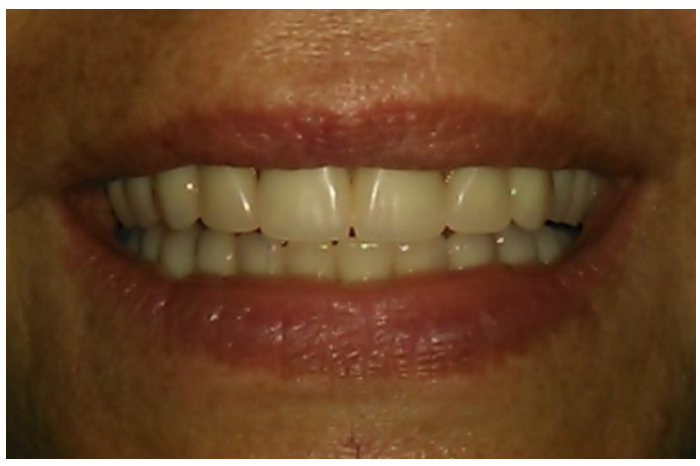

\section{DISCUSSION}

The present case series describes prosthodontic rehabilitation of patients with double crown and locator atachmentsretained overdentures supported by a combination of natural tooth and strategic implants. Namely, the rehabilitation of an partially edentulous jaw with only a few remaining teeth often requires the use of implants as supplementary abutments to increase favorable support zone (quadrangular or triangular), patient comfort and satisfaction. However, the combination of teeth and implants for the support of removable partial denture (RPD) has been rarely described in the literature $(15,16,18-22)$. Previous studies $(16,18,21,22)$ have reported survival and prosthetic complications for combined tooth-implant-supported overdentures on double crowns as homogenous anchorage element on teeth and implants. The results of these studies revealed that the tooth-implant supported double crown-retained overdentures had high implant survival rate of $92 \%$ to $100 \%$ after observation period of 3 to 6 years $(16,18,21,22)$. Furthermore, a few clinical investigations $(15,16,21,22)$ showed that combination of implants and teeth for the support of double-crowns retained-overdentures did not result in more biological and technical complications than for dentures retained exclusively on implants or natural teeth. Also, the literature reported that several factors such as the selection of remaining teeth, the total number and the strategic distribution of the abutments are very important to the long term success of these types of prosthodontic options $(15,20,22)$.

On the other side, Chen et al. (23) in its biomechanical study focused on the biomechanical behaviors of natural teeth in combined tooth-implant double-crown-retained prostheses. They reported that the combination of teeth and implants in rigid connectors acts as a cantilever and the highest stress concentration was observed at cortical region around the implants under loading. Also, the authors showed that the treatment of combined tooth-implant supported double crown prosthesis could protect teeth and their periodontal support tissues through relieving their loading during bearing masticatory forces, acting as a rigid splint. This finding is in line with results of clinical studies $(16,22,24)$, in which no tooth intrusion has been reported.

In the present case series, we showed prosthetic treatments of patients with combined tooth-implant-supported overdentures retained double crown and locator attachments as heteregenous connecting elements on tooth and implants. The major advantages of this treatment option are good denture's retention and stability, improved chewing performance, good esthetic outcome and low cost. Also, keeping one or a few remaining teeth provide tactility and the reflex control of the masticatory system by the periodontal mechanoreceptors. However, in the literature, we found only two studies $(16,19)$ in which the authors used heteregenous anchorage elements on tooth and implants for combined toothimplant-supported RPDs. Kaufmann et al. (19) investigated telescopic crowns and ball attachments as connecting elements for combined tooth-implant-supported overdenture. In this study, higher technical complication rate was observed for overdentures retained telescopic crowns and ball attachments as anchors than for dentures retained a uniform attachment system $(18,21)$. On contrary, Hug et al. (16) using the same anchorage elements showed that technical complications and service performed were significantly higher in the tooth root group than in implant and combined tooth-implant groups. However, satisfaction, dentures's stability, comfort and speaking ability improved in implants supported RPD wearers compared with combined or exclusive root supported RPD wearers.

\section{CONCLUSION}

The presented treatment resulted improved functionality, comfort, aesthetics and stability after poorly fitting dentures were replaced with new, better-fitting ones. The use of double crown and locator attechments on tooth and implants to retain overdentures is reliable treatment option and can be integrated into treatment planning for patients with a highly reduced dentition. Further prospective studies on more patients are needed to confirm the results presented in this case series and to compare this treatment option with other treatment concepts. 


\section{REFERENCE}

1. John MT, Koepsell TD, Hujoel P, Miglioretti DL, Leresche L, Micheelis W. (2004). Demographic factors, denture status and oral health-related quality of life. Community. Dent. Oral. Epidemiol. 32: 125-132. DOI:10.1111/j.0301-5661.2004.00144.x

2. Gerritsen AE, Allen PF, Witter DJ, Bronkhorst EM, Creugers NH. (2010). Tooth loss and oral health-related quality of life: a systematic review and metaanalysis. Health. Qual. Life. Outcomes. 8: 126. DOI: 10.1186/1477-7525-8-126.

3. Kovačić I, Čelebić A, Knezović-Zlatarić D, Stipetić J, Papić M. (2003). Influence of Body Mass Index and the Time of Edentulousness on the Residual Alveolar Ridge Resorption in Complete Denture Wearers. Coll. Antropol. 27(2): 69-74.

4. Knezović-Zlatarić D, Čelebić A, Kovačić I, Mikelić Vitasović B. (2008). Linear Vertical Jaw Resorption Potential in Elderly Complete Denture Wearers: A Five-Year Follow-Up Study. Coll. Antropol. 32(3): 907-912.

5. Atwood DA, Coy WA. (1971). Clinical, cephalometric, and densiometric study of reduction of residual ridges. J. Prosthet. Dent. 26: 280-295. DOI: 10.1016/0022-3913(71)90070-9

6. Tallgren A. (1972). The continuing reduction of the residual alveolar ridges in complete denture wearers: a mixed-longitudinal study covering 25 years. J. Prosthet. Dent. 27: 120-132. DOI: 10.1016/00223913(72)90188-6

7. Kutkut A, Bertoli E, Frazer R, Pinto-Sinai G, Fuentealba Hidalgo R, Studts J. (2017). A systematic review of studies comparing conventional complete denture and implant retained overdenture. J. Prosthodont. Res. (17) 30068-3 DOI: 10.1016/j.jpor.2017.06.004

8. Batenburg RH, Meijer HJ, Raghoebar GM, Vissink A. (1998). Treatment concept for mandibular overdentures supported by endosseous implants: a literature review. Int. J. Oral. Maxillofac. Implants. 13: 539-545.

9. Arora V, Kumar D, Legha VS, Arun Kumar KV. (2014). Prospective study of treatment outcome of implantretained mandibular overdenture: Two years follow-up. Contemp. Clin. Dent. 5(2): 155-159. DOI: 10.4103/0976-237X.132304

10. Mengel R, Kreuzer G, Lehmann KM, Flores-deJacoby L. (2007). A telescopic crown concept for the restoration of partially edentulous patients with aggressive generalized periodontitis: a 3-year prospective longitudinal study. Int. J. Periodontics. Restorative. Dent. 27: 231-239.

11. Hoffmann O, Beaumont C, Tatakis DN, Zafiropoulos G. (2006). Telescopic crowns as attachments for implant supported restorations: a case series. J. Oral. Implantol. 32: 291-299. DOI: 10.1563/0-815.1
12. Zou D, Wang F, Wu Y, Huang W, Zhang C, Zhang Z. (2015). Implant-Supported Telescopic Crown-Retained Overdentures for Oral Rehabilitation of Patients with Severe Bony Defects: A 5-Year Retrospective Study. Int. J. Oral. Maxillofac. Implants. 30(4): 937944 DOI: $10.11607 /$ jomi.3697

13. Morandi R, Cabral LM, de Moraes M. (2016). Implantsupported maxillary denture retained by a telescopic abutment system: A clinical report. J. Of. Prosthetic. Dent. 117(3): 331-334. DOI: 10.1016/j.prosdent.2016.06.013

14. Karabuda C, Tosun T, Ermis E, Ozdemir T. (2002). Comparison of 2 retentive systems for implant - supported overdentures: soft tissue management and evaluation of patient satisfaction. J. Periodontol. 73: 10671070. DOI: 10.1902/jop.2002.73.9.1067

15. Bernhart G, Koob A, Schmitter M, et al. (2012). Clinical success of implant-supported and tooth-implantsupported double crown-retained dentures. Clin. Oral. Invest. 16: 1031-1037. DOI: 10.1007/s00784-0110592-1

16. Hug S, Mantokoudis D, Mericske-Stern R. (2006). Clinical evaluation of 3 overdenture concepts with tooth roots and implants: 2-year results. Int. J. Prosthodont. 19: 236-243.

17. Ochiai KT, Williams BH, Hojo S, et al. (2004). Photoelastic analysis of the effect of palatal support on various implant-supported overdenture designs. J. Prosthet. Dent. 91: 421-427. DOI: 10.1016/j.prosdent.2004.02.017

18. Rinke S, Ziebolz D, Ratka-Krüger P, Frisch E. (2015). Clinical Outcome of Double Crown-Retained Mandibular Removable Dentures Supported by a Combination of Residual Teeth and Strategic Implants. J. Prosthodont. 24(5): 358-365. DOI: 10.1111/jopr.12214

19. Kaufmann R, Friedli M, Hug S, et al. (2009). Removable dentures with implant support in strategic positions followed for up to 8 years. Int. J. Prosthodont. 22: 233-241.

20. Krennmair G, Krainh“ofner M, Waldenberger O, et al. (2007). Dental implants as strategic supplementary abutments for implant-tooth-supported telescopic crown-retained maxillary dentures: a retrospective follow-up study for up to 9 years. Int. J. Prosthodont. 20: 617-622.

21. Schwartz S, Bernhart G, Hassel AJ, Rammelsberg P. (2014). Survival of double-crown-retained dentures either tooth-implant or solely implant-supported: an 8year retrospective study. Clin. Implant. Dent. Relat. Res. 16(4): 618-625. DOI: 10.1111/cid.12023

22. Rammelsberg P, Bernhart G, Bermejo JL, Schmitter M, Schwarz S. (2014). Prognosis of implants and abutment teeth under combined tooth-implant-supported and solely implant-supported double-crown-retained removable dental prostheses. Clin. Oral. Implants. Res. 25: 813-818. DOI: 10.1111/clr.12197 
23. Chen $Y$, Wang C, Huang Y, Feng T, Zou H, Fan Y. (2017). Biomechanical evaluation of the natural abutment teeth in combined tooth-implant-supported telescopic prostheses: a three-dimensional finite element analysis. Comput. Methods. Biomech. Biomed. Engin. 20(9): 967-979. DOI: 10.1080/10255842.2017. 1319941
24. Frisch E, Ratka-Krüger P, Wenz HJ. (2015). Unsplinted implants and teeth supporting maxillary removable partial dentures retained by telescopic crowns: a retrospective study with $>6$ years of followup. Clin. Ora.l Implants. Res. 26(9): 1091-1097. DOI: 10.1111/clr.12407 